\title{
Emergence of peraluminous crustal magmas and implications for the early Earth
}

\author{
M.R. Ackerson ${ }^{1 *}$, D. Trail ${ }^{2}$, J. Buettner ${ }^{3}$
}

Abstract

doi: $10.7185 /$ geochemlet.2114

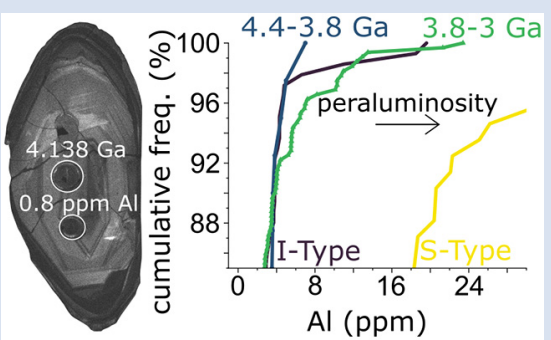

Detrital zircons from the Jack Hills $(\mathrm{JH})$ metasedimentary belt of Western Australia are a record of the first $\sim 1.5$ billion years of Earth history and can be used to help reconstruct the conditions of crust formation and secular changes therein. Beginning as early as ca. $4.3 \mathrm{Ga}$, but becoming more pronounced in the midArchean, a peraluminous signature begins to emerge from the $\mathrm{JH}$ zircon record. Combined with trace elements (P, REEs) and Ti-in-zircon thermometry, this increase in peraluminosity is likely the result of deep ( $>7 \mathrm{kbar}$ ) partial melting of hydrous mafic protoliths or partial melting of metasedimentary source material. In a geodynamic context, these results may suggest a gradual shift from a vertical tectonic regime toward a horizontal tectonic regime with potential subduction-like or collisional processes creating the necessary conditions for peraluminous melt generation beginning locally at least by $\sim 3.6$ billion years ago (Ga).

Received 17 June 2020 | Accepted 19 March 2021 | Published 14 May 2021

\section{Introduction}

Continental crust and its derivatives (e.g., detrital zircons) preserve a near continuous record of Earth's history from 4.4. Ga to today (Voice et al., 2011) that can be used to investigate both individual magmatic systems (e.g., Reimink et al., 2014) and secular changes in Earth's geodynamic and tectonic history (Bauer et al., 2020). The 3 Ga metasedimentary rocks from the $\mathrm{JH}$ in Western Australia contain detrital zircons that are the oldest known record of Earth's continents (Compston and Pidgeon, 1986). These ancient zircons retain multiple chemical fingerprints that have been combined to reconstruct a Hadean Earth that bore oxidised, water-rich silicic continents derived from mafic $( \pm$ felsic) protoliths that interacted with low temperature (T) surface waters (Cavosie et al., 2005; Watson and Harrison, 2005; Trail et al., 2011; Burnham and Berry, 2017).

One outstanding problem in Earth's early history is the nature and timing of the transition from a stagnant lid or vertical tectonic regime (crust thickened by processes akin to modern oceanic plateaus; Van Kranendonk et al., 2004; Reimink et al., 2014) to a mobile lid or horizontal tectonic regime where crust can be thickened and rapidly recycled through subduction-like processes and/or shallow thrusting (Bauer et al., 2020). Horizontal tectonics is associated with an increase in the depth of melt generation. The shift toward a horizontal tectonic regime should produce chemical signatures in the ancient rock record that reflect this geodynamic shift. One potential tool to evaluate this shift is the $\mathrm{Al}$ content of zircon crystals $\left(X_{\mathrm{Al}}^{\mathrm{Zrc}}\right.$, in ppm by weight), which is strongly dependent on the peraluminosity of the melt from which the zircon crystallised (Wang and Trail, 2019).

Experiments and natural observations indicate that peraluminous melts (here defined as those with an aluminum saturation index $\left[\mathrm{ASI}=\right.$ molar $\left.\mathrm{Al}_{2} \mathrm{O}_{3} /\left(\mathrm{CaO}+\mathrm{Na}_{2} \mathrm{O}+\mathrm{K}_{2} \mathrm{O}\right)\right]>1$ (Shand, 1943) are the product of a limited number of petrogenetic processes. Here, we investigate $\mathrm{X}_{\mathrm{Al}}^{\mathrm{Zrc}}$ from the JH as an indicator of peraluminous melts and relate this to petrogenetic models in the context of geodynamic shifts in the first $\sim 1.5$ billion years of Earth's history.

\section{Samples and Results}

Zircons were collected from clastic metasedimentary units within the Jack Hills metamorphic belt (Weiss et al., 2015). All zircons were separated from their host rock and mounted in epoxy using previously described techniques (Trail et al., 2017; also see Supplementary Information). Care was taken to ensure the trace element compositions reported for zircons are primary structure bound signatures (e.g., not metamict regions, mineral inclusions, secondary alterations). Data were discarded if: 1) Fe $>100$ ppm, 2) analyses outside $100 \pm 10 \%$ concordance, and/or 3) light rare earth element index (LREE-I) < 50 (Bell et al., 2019).

The cumulative zircon age distribution is similar to previously reported ages from the JH (e.g., Crowley et al., 2005), with notable age peaks at 3370 and 4050 Ma (Fig. 1). Exceptionally, site T145 contained a high proportion $(15.5 \%)$ of unaltered Hadean-aged zircons. Zircon titanium concentrations are similar

\footnotetext{
Department of Mineral Sciences, National Museum of Natural History, Smithsonian Institution, Washington, DC

Department of Earth and Environmental Sciences, University of Rochester, Rochester, NY

Los Alamos National Laboratory, Los Alamos, NM

Corresponding author (email: ackersonm@si.edu)
} 
(a)
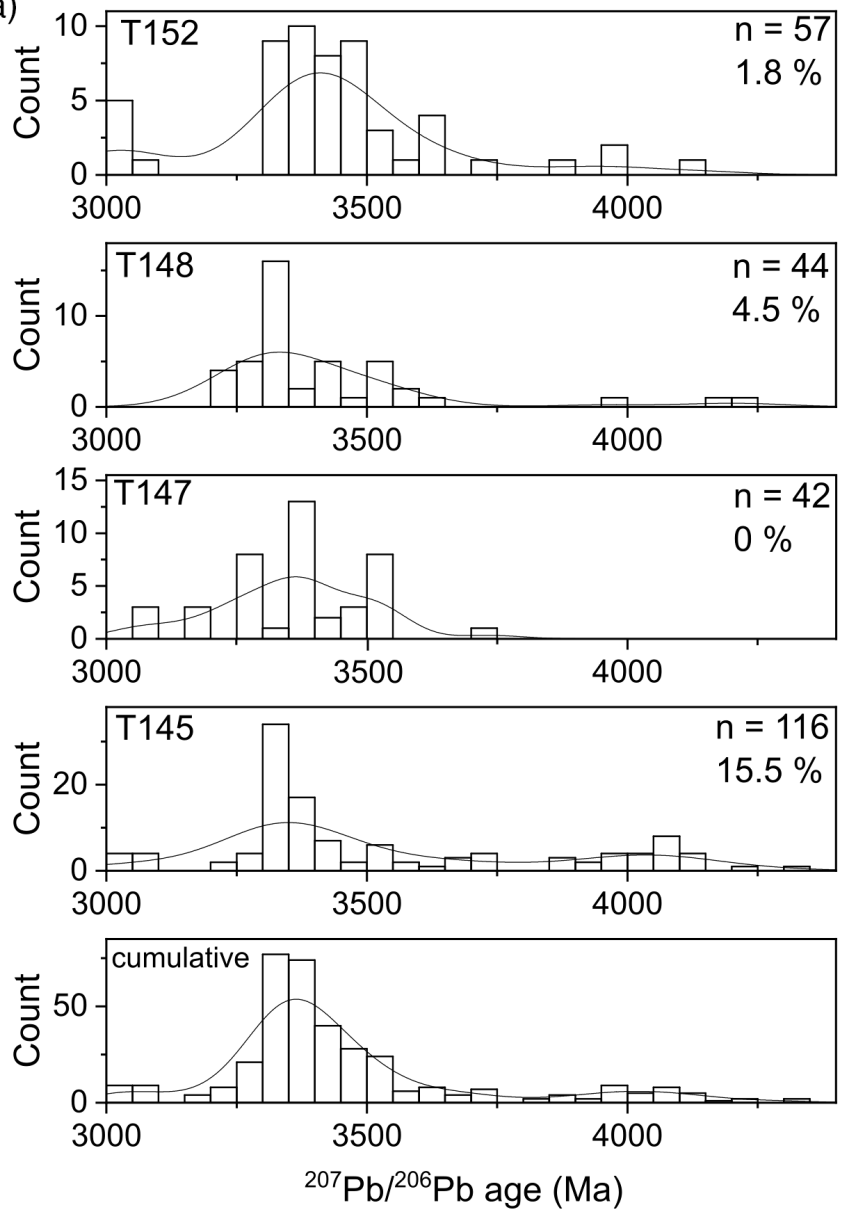

(b)

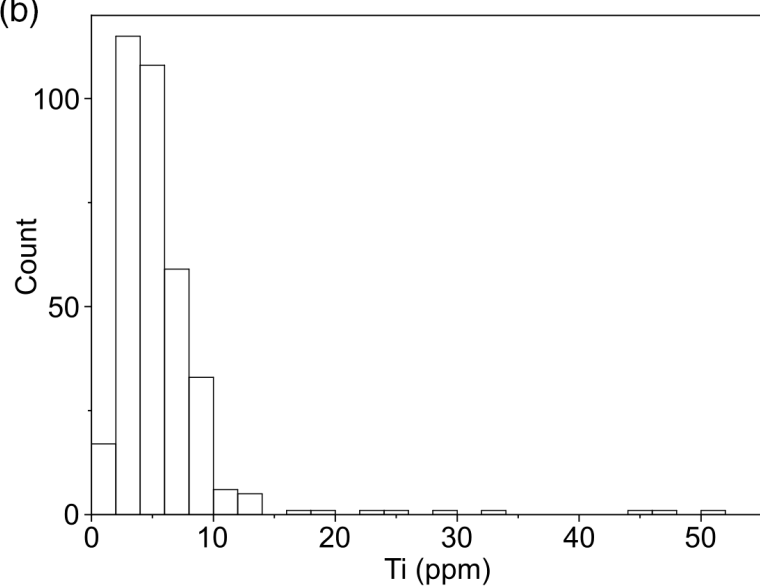

(c)

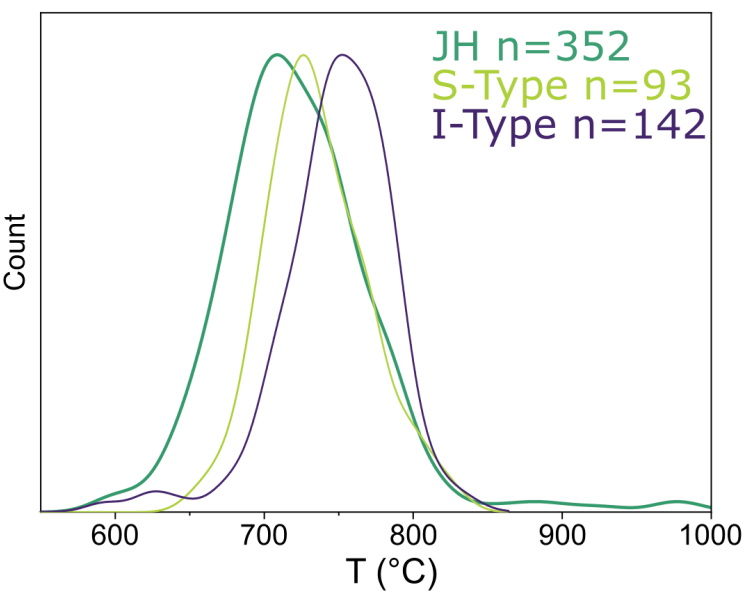

Figure 1 (a) ${ }^{207} \mathrm{~Pb} /{ }^{206} \mathrm{~Pb} \mathrm{JH}$ zircon age distributions from multiple units. (b) $\mathrm{Ti}$ in JH zircons with (c) Ti-in-zircon temperatures, calculated assuming $a_{\mathrm{TiO}_{2}}=0.5$ and $a_{\mathrm{SiO}_{2}}=0.8$ (Ferry and Watson, 2007) with zircons from the LFB (Trail et al., 2017).

to other studies of the JH (e.g., Watson and Harrison, 2005), and broadly indicate crystallisation from cool, water saturated intrusive igneous systems (Fig. 1). Age versus $X_{\mathrm{Al}}^{\mathrm{Zrc}}$ (Fig. 2) shows an increase in both the number of high $\mathrm{Al}(>4 \mathrm{ppm} \mathrm{Al})$ and the average $\mathrm{Al}$ content of zircons beginning by $\sim 3.6 \mathrm{Ga}$ (Fig. 2).

\section{Discussion}

Al-in-zircon as a proxy for peraluminosity. $\mathrm{X}_{\mathrm{Al}}^{\mathrm{Zrc}}$ is influenced by melt composition, temperature and water content $\left(\mathrm{Al}^{3+}+\mathrm{H}^{+}=\right.$ $\mathrm{Si}^{4+}$ ) (Trail et al., 2017; Wang and Trail, 2019). These parameters will co-vary in a magmatic system, and a magmatic liquid cooling along a liquid line of descent will generally increase peraluminosity and water content with decreasing temperature (e.g., Blatter et al., 2013). However, JH zircons record a narrow range of temperatures (Fig. 1). These temperatures indicate crystallisation from a cool, water-rich silicic magma which suggests that variations in water activity play a subordinate role in regulating $\mathrm{X}_{\mathrm{Al}}^{\mathrm{Zrc}}$. The weak correlation between $\mathrm{Al}$ and Ti (Fig. S-5) suggests $\mathrm{T}$ also plays a subordinate role to composition in regulating $\mathrm{X}_{\mathrm{Al}}^{\mathrm{Zrc}}$ within this population (Trail et al., 2017). The dominant role of composition is further demonstrated in granitic zircons from the Lachlan Fold Belt (LFB), the type locality of I- and S-type granitic rocks [defined here as granitic rocks known to primarily form through igneous processes (I-type) versus those formed to a measurable extent by melting of metasedimentary precursors (S-types); e.g., Chappell, 1999]. It should be noted that I-type magmas are often weakly peraluminous (ASI $<1.1$ ), and as such bulk peraluminosity is not used here to define I- versus S-type magmas. In the LFB, even though Ti content of I-type zircons is slightly higher on average than S-types, the latter have significantly higher $\mathrm{X}_{\mathrm{Al}}^{\mathrm{Zrc}}$ (Fig. S-4)

Increasing peraluminosity results in increased alumina activity and a subsequent increase in $\mathrm{X}_{\mathrm{Al}}^{\mathrm{Zrc}}$. For granitic zircons of the LFB, $X_{\mathrm{Al}}^{\mathrm{Zrc}}$ exceeds $4 \mathrm{ppm}$ when the bulk composition becomes peraluminous, likely reflecting this increase in alumina activity in the melt (Trail et al., 2017). We use this $4 \mathrm{ppm}$ value to discriminate between zircons that likely crystallised from peraluminous melts. It is worth noting that $\sim 80 \%$ of JH zircons have $\mathrm{Al}$ contents lower than the LFB I-types (Fig. 2b), which reflects the lower crystallisation T observed in the Ti content (Fig. 1c). Thus, this LFB based peraluminosity threshold likely underestimates the number of peraluminous JH zircons.

In the $\mathrm{JH}$, there is a subtle but significant increase in $X_{\mathrm{Al}}^{\mathrm{Zrc}}$ with decreasing age (Fig. 2b). The $>3.8$ Ga population yields $\mathrm{X}_{\mathrm{Al}}^{\mathrm{Zrc}}$ similar to I-type granitoids. In the 3.8-3 Ga population, likely peraluminous zircons ( $>4 \mathrm{ppm} \mathrm{Al}$ ) have an average $X_{\mathrm{Al}}^{\mathrm{Zrc}}=8.5$ ppm compared to $X_{\mathrm{Al}}^{\mathrm{Zrc}}=5.5 \mathrm{ppm}$ in the $>3.8$ Ga group and $X_{\mathrm{Al}}^{\mathrm{Zrc}}=7.8 \mathrm{ppm}$ in I-types. As the JH is a metasedimentary rock, this increase is akin to sedimentary mixing of metaluminous [ASI $<1$, molar $\mathrm{Al}_{2} \mathrm{O}_{3} /\left(\mathrm{Na}_{2} \mathrm{O}+\mathrm{K}_{2} \mathrm{O}\right)>1$ ] and peraluminous protoliths seen in modern sedimentary systems (Fig. S-7).

Origin of peraluminous zircons. The limited number of mechanisms to generate peraluminous melts makes their appearance in the $\mathrm{JH}$ record a useful event for interpreting 

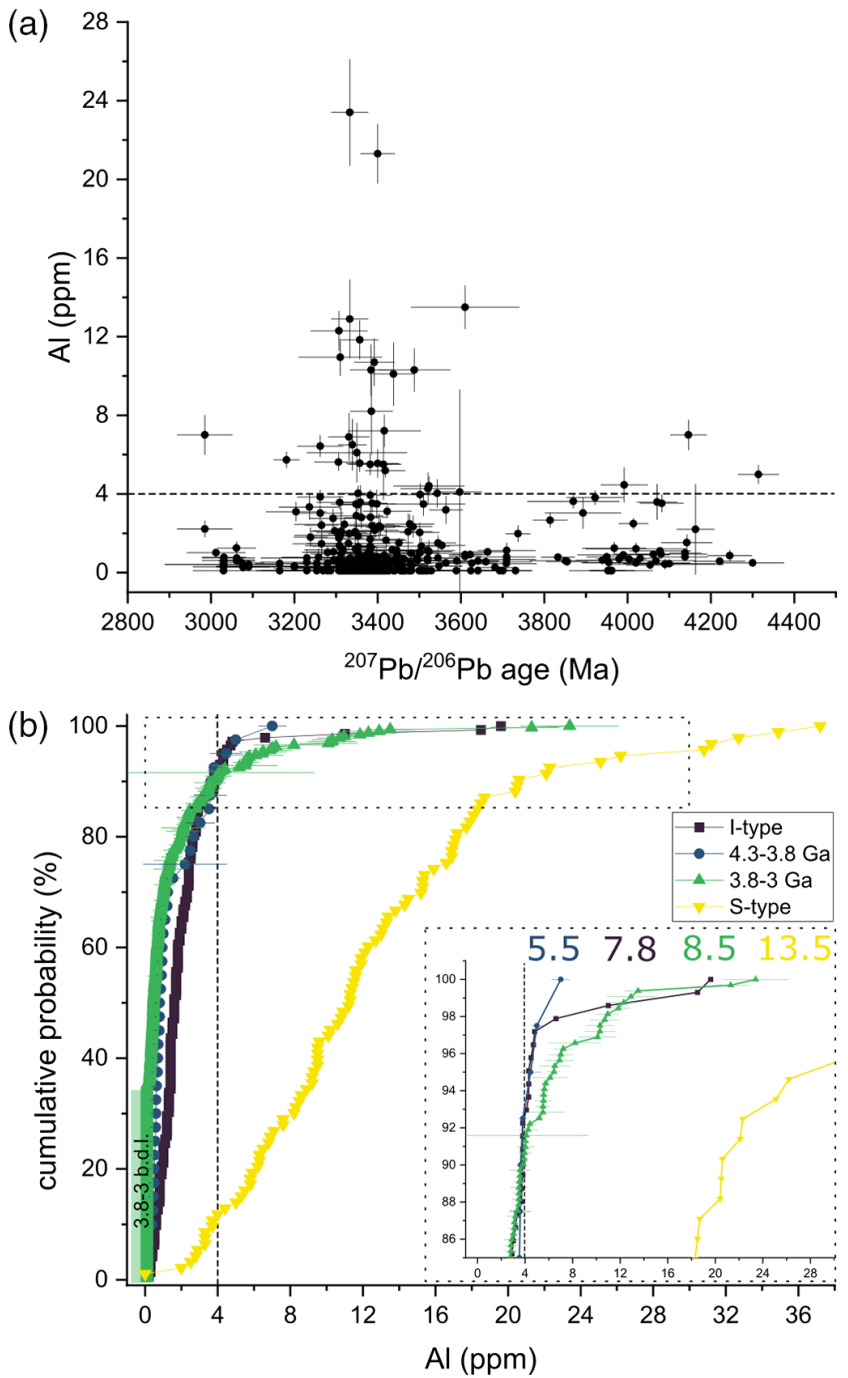

Figure 2 (a) Age versus Al concentration for $\mathrm{JH}$ zircons, error bars are $2 \sigma$. Zircons with $X_{A I}^{Z r c}$ below detection limit (b.d.I.) are indicated at base of the diagram. Horizontal dashed line at $4 \mathrm{ppm}$ Al defines zircons that likely formed from peraluminous melts. (b) Cumulative probability diagram of I- and S-type LFB (Trail et al., 2017) and age binned JH zircons. Numbers in inset are average $X_{A l}^{Z r c}$ for $X_{A l}^{Z r c}>$ $4 \mathrm{ppm}$ zircon populations from each group.

tectonic shifts on the early Earth. Experiments and investigations of modern magmatic systems have demonstrated multiple mechanisms to produce peraluminous magmas, including: (1) late stage differentiation of silicic "I-type" granitic magmas, (2) melting and incorporation of metasedimentary material, and (3) partial melting or fractionation of hydrous mafic parent material at $>7 \mathrm{kbar}$.

Late stage differentiation of metaluminous I-type bulk compositions can produce weakly peraluminous melts. However, this peraluminosity yields a negligible amount of zircon (Trail et al., 2017). Similarly, I-type systems can also evolve toward weakly peraluminous bulk compositions (Chappell, 1999 and sources therein), but peraluminous I-type zircons have similar compositions to their metaluminous counterparts (Fig. 3).

On Earth today, the most volumetrically significant way to produce strongly peraluminous melts is through melting of weathered sediments (e.g., psammites, metapelites) (Patiño Douce and Johnston, 1991). Based on a P versus REE (or Dy) discrimination diagram that records the increase in $\mathrm{P}$ content of apatite saturated peraluminous melts, zircons from the Jack
Hills have been dismissed as being derived from peraluminous melts (Burnham and Berry, 2017). However, there is significant overlap at low $\mathrm{P}$ content between peraluminous S-type and metaluminous and weakly peraluminous I-type granitoids (Fig. 3). Although the JH zircons do not exhibit high P-Dy signals, the overlap at low P content between S-type and I-type zircons makes it difficult to rule out metasediments as a source of some JH zircons, and does not discount previous work suggesting a potential sedimentary source for some JH zircons (Bell et al., 2015).

In lieu of metasediment melting, moderate pressure fractionation of hydrous mafic material could produce peraluminous zircons in excess of those found in modern I-type granitoids. At pressures greater than $\sim 7 \mathrm{kbar}$, hydrous mafic magmas can produce alumina-rich melts via crystallisation of $\mathrm{Ca}$-rich pyroxene and suppression of plagioclase crystallisation (Müntener and Ulmer, 2006; Blatter et al., 2013), and at pressures within the garnet stability field ( $\geq 10 \mathrm{kbar}$ ), incongruent melting of amphibole and biotite in metaluminous bulk compositions can produce alumina-rich melts and pyroxene (Chappell et al., 2012). These moderate pressure processes lead to the generation of peraluminous melts at lower bulk $\mathrm{SiO}_{2}$ ( 60 wt. $\% \mathrm{SiO}_{2}$ versus $\sim 70$ wt. \% $\mathrm{SiO}_{2}$ ) than modern arcs magmas (Fig. 4), which in turn could yield a higher proportion of peraluminous zircons than modern arcs.

Implications for early Earth geodynamics. The distribution of $\mathrm{X}_{\mathrm{Al}}^{\mathrm{Zrc}}$ of JH zircons $>3.8 \mathrm{Ga}$ is similar to modern I-type magmas (Fig. 2), whose intermediate compositions overlap in $\mathrm{SiO}_{2}$-ASI space with $>4 \mathrm{Ga}$ granitoids from the Acasta Gneiss Complex (AGC) that have been interpreted as crystallising from an environment akin to modern oceanic plateaus (Reimink et al., 2014) at 3-4 kbar (Fig. 4). On the ancient Earth, this is consistent with crystallisation in a vertical tectonic regime prior to $3.8 \mathrm{Ga}$, and is further supported by other chemical similarities between pre-4 Ga AGC and JH zircons (Reimink et al., 2019a).

Pre- and post-3.8 Ga JH and I-type populations cross the $4 \mathrm{ppm} \mathrm{Al}$ threshold at roughly the same cumulative probability ( $90 \%)$. However, the average $\mathrm{Al}$ content of the likely peraluminous post-3.8 Ga zircons is greater than either the pre-3.8 or I-type populations. This potentially indicates a different and strongly peraluminous source to the 3.8-3 Ga group. Regardless of whether the peraluminous zircons are derived from metasedimentary sources or moderate high pressure fractionation processes, both scenarios likely require a geodynamic shift toward horizontal tectonics. For sediment melting, weathered continental material is required to be brought to depths great enough to be melted. For deep mafic melting, hydrated near surface mafic material needs to be brought to moderate pressures ( $\geq 7 \mathrm{kbar}$ ) in order to melt and fractionate. Although it is possible for hydrated mafic material to be brought to depths through vertical tectonic processes, the relative short timescales invoked to account for the shift in $\varepsilon^{176} \mathrm{Hf}$ observed from $\mathrm{JH}$ and other ancient zircons (Bauer et al., 2020), similarities in trace element content between JH and AGC zircons (Reimink et al., 2019a), and the onset of peraluminosity indicate a shift toward a horizontal tectonic regime.

Whereas peraluminous granitic rocks dominate the bedrock geology in the AGC at 3.6 Ga (Reimink et al., 2019b), the peraluminous zircons that emerge in the JH record at $\sim 3.6$ Ga are only a fraction of the total zircon population ( 10\%). This could indicate preservation bias of the peraluminous rocks of the AGC, preservation of more diverse protoliths in the detrital JH zircons, or a globally heterogeneous distribution of crust-forming processes $\mathrm{ca}$. 3-3.6 Ga. Regardless, the emergence of significant peraluminous zircons in the JH conforms with observations from other ancient crustal systems (e.g., 
(a)
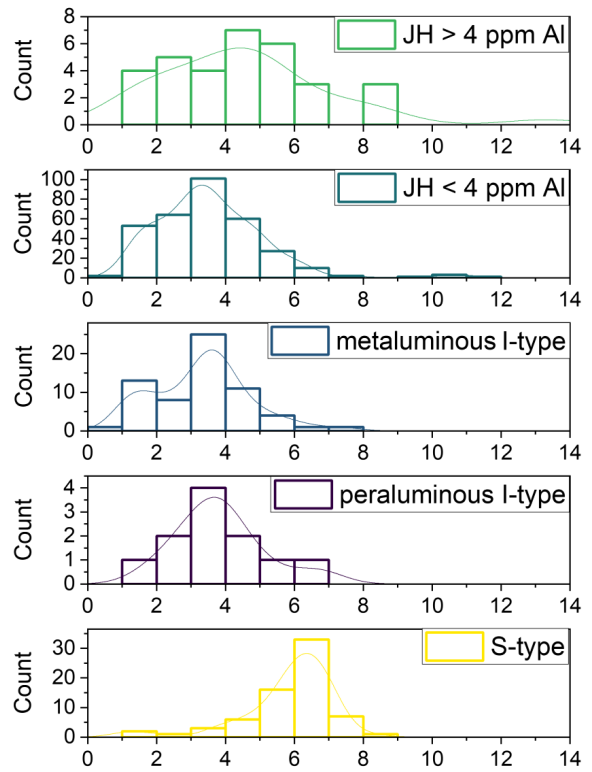

P/Dy (b)

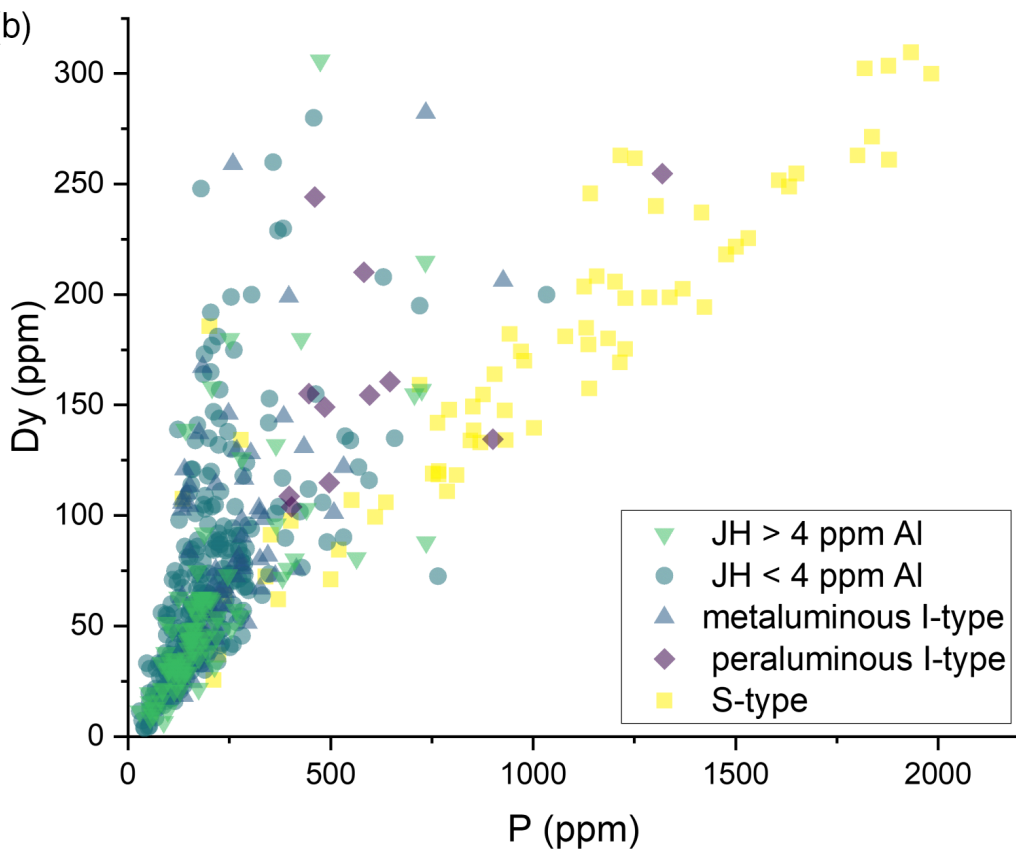

Figure 3 (a) Histograms of P/Dy ratios and (b) scatterplot of P and Dy concentrations in zircons from l-type and S-type LFB granitoids compared with likely peraluminous $\left(\mathrm{X}_{\mathrm{Al}}^{\mathrm{Zrc}}>4 \mathrm{ppm}\right)$ and non-peraluminous $\mathrm{JH}$ zircons. On the whole, peraluminous zircons from the $\mathrm{JH}$ have higher P/Dy ratios than non-peraluminous JH, and their median value of P/Dy is higher than that of peraluminous I-types. LFB data from (Burnham and Berry, 2017).

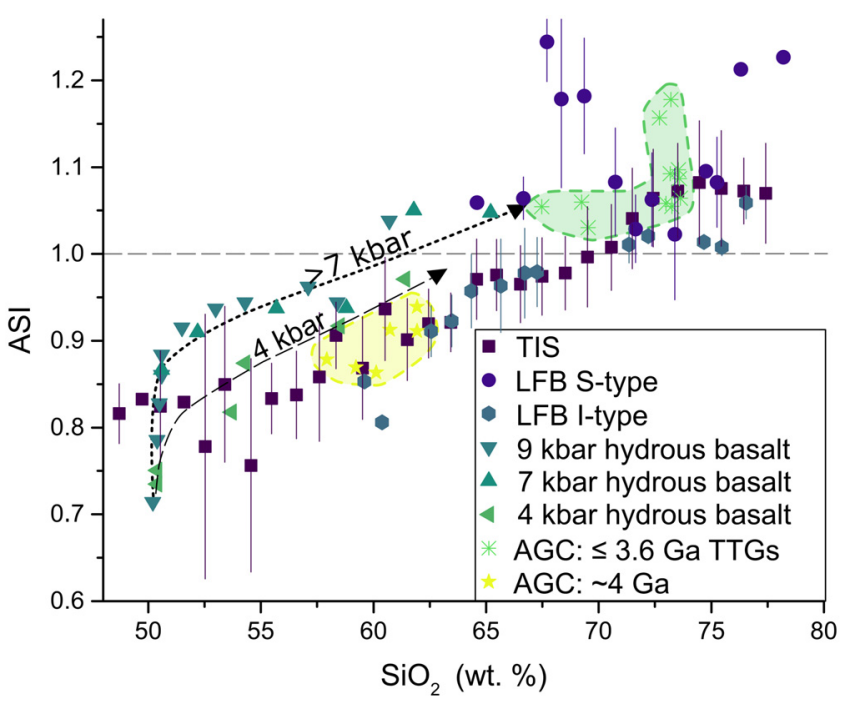

Figure $4 \mathrm{SiO}_{2}$ versus $\mathrm{ASI}$ for common magmatic rocks and melts. LFB and Tuolumne Intrusive Suite (TIS) intrusive rocks binned in 1 wt. $\% \mathrm{SiO}_{2}$ increments, error bars are $1 \sigma$. I-type granitic rocks from the LFB (Griffin et al., 1978; Chappell and White, 1992) and intrusive rocks from the TIS (Bateman et al., 1984; Ratajeski et al., 2001) become peraluminous at $\sim 70 \mathrm{wt} \% \mathrm{SiO}_{2}$, whereas hydrous basalts fractionated at depths $\geq 7 \mathrm{kbar}$ can produce melts that become peraluminous at $\sim 60 \mathrm{wt}$. $\% \mathrm{SiO}_{2}$, unlike those fractionated at lower pressures (Blatter et al., 2013).

AGC, Pilbara Craton; Bauer et al., 2020) of a geodynamic shift toward horizontal tectonics by at least $\sim 3.6 \mathrm{Ga}$.

\section{Acknowledgements}

We thank J. Reimink, R. Fu, A.C. Maloof, N.D. Tailby, and B.P. Weiss for scientific discussions and T. Freeman, A. Sharma,
J.P. Hurtado Padilla and the SI YES! Internship programme for imaging zircons. This work partially supported by NASA PC3 grant 80NSSC19M0069.

Editor: Maud Boyet

\section{Additional Information}

Supplementary Information accompanies this letter at https:// www.geochemicalperspectivesletters.org/article2114.

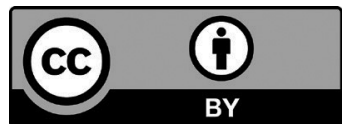

(C) 2021 The Authors. This work is distributed under the Creative Commons Attribution 4.0 License, which permits unrestricted use, distribution, and reproduction in any medium, provided the original author and source are credited. Additional information is available at http://www.geochemicalperspectivesletters.org/ copyright-and-permissions.

Cite this letter as: Ackerson, M.R., Trail, D., Buettner, J. (2021) Emergence of peraluminous crustal magmas and implications for the early Earth. Geochem. Persp. Let. 17, 50-54.

\section{References}

Bateman, P.C., Dodge, F.C.W., Bruggman, P.E. (1984) Major oxide analyses, CIPW norms, modes, and bulk specific gravities of plutonic rocks from the Mariposa $1^{\circ} \times 2^{\circ}$ sheet, central Sierra Nevada, California. US Geological Survey Open-File Report 84-162.

Bauer, A.B., Reimink, J.R., Chacko, T., Foley, B.J., Shirey, S.B., Pearson, D.G. (2020) Hafnium isotopes in zircons document the gradual onset of mobile-lid tectonics. Geochemical Perspectives Letters 14, 1-6.

Bell, E.A., BoehnKe, P., Harrison, T.M., Mao, W.L. (2015) Potentially biogenic carbon preserved in a 4.1 billion-year-old zircon. Proceedings of the National Academy of Sciences 112, 14518-14521. 
Bell, E.A., BoeHnKe, P., Barboni, M., HarRison, T.M. (2019) Tracking chemical alteration in magmatic zircon using rare earth element abundances. Chemical Geology 510, 56-71.

BlatTeR, D.L., Sisson, T.W., HANKINS, W.B. (2013) Crystallization of oxidized, moderately hydrous arc basalt at mid- to lower-crustal pressures: implications for andesite genesis. Contributions to Mineralogy and Petrology 166, 861-886.

BURNHAM, A.D., BERRY, A.J. (2017) Formation of Hadean granites by melting of igneous crust. Nature Geoscience 10, 457-461.

Cavosie, A.J., Valley, J.W., Wilde, S.A., E.I.M.F. (2005) Magmatic $\delta^{18} \mathrm{O}$ in 4400 3900 Ma detrital zircons: A record of the alteration and recycling of crust in the Early Archean. Earth and Planetary Science Letters 235, 663-681.

Chappell, B.W. (1999) Aluminium saturation in I- and S-type granites and the characterization of fractionated haplogranites. Lithos 46, 535-551.

Chappell, B.W., White, A.J.R. (1992) I- and S-type granites in the Lachlan Fold Belt. Earth and Environmental Science Transactions of the Royal Society of Edinburgh $83,1-26$.

Chappell, B.W., Bryant, C.J., Wyborn, D. (2012) Peraluminous I-type granites. Lithos 153, 142-153.

Compston, W., Pidgeon, R.T. (1986) Jack Hills, evidence of more very old detrital zircons in Western Australia. Nature 321, 766-769.

Crowley, J.L., Myers, J.S., Sylvester, P.J., Cox, R.A. (2005) Detrital Zircon from the Jack Hills and Mount Narryer, Western Australia: Evidence for Diverse $>4.0$ Ga Source Rocks. The Journal of Geology 113, 239-263.

FERRY, J.M., WATSON, E.B. (2007) New thermodynamic models and revised calibrations for the Ti-in-zircon and $\mathrm{Zr}$-in-rutile thermometers. Contributions to Mineralogy and Petrology 154, 429-437.

Griffin, T.J., White, A.J.R., Chappell, B.W. (1978) The Moruya Batholith and geochemical contrasts between the Moruya and Jindabyne suites. Journal of the Geological Society of Australia 25, 235-247.

MÜNTENER, O., UlmER, P. (2006) Experimentally derived high-pressure cumulates from hydrous arc magmas and consequences for the seismic velocity structure of lower arc crust. Geophysical Research Letters 33, L21308.

Patiño Douce, A.E., Johnston, A.D. (1991) Phase equilibria and melt productivity in the pelitic system: implications for the origin of peraluminous granitoids and aluminous granulites. Contributions to Mineralogy and Petrology 107 202-218.

Ratajeski, K., GlazNeR, A.F., Miller, B.V. (2001) Geology and geochemistry of mafic to felsic plutonic rocks in the Cretaceous intrusive suite of Yosemite Valley, California. Geological Society of America Bulletin 113, 1486-1502.

ReiminK, J.R., CHACKO, T., SteRn, R.A., HeAman, L.M. (2014) Earth's earliest evolved crust generated in an Iceland-like setting. Nature Geoscience 7, 529-533.

ReiminK, J.R., Davies, J.H.F.L., BAUER, A.M., CHAcko, T. (2019a) A comparison between zircons from the Acasta Gneiss Complex and the Jack Hills region. Earth and Planetary Science Letters 531, 115975.

Reimink, J.R., Pearson, D.G., Shirey, S.B., Carlson, R.W., Ketchum, J.W.F. (2019b) Onset of new, progressive crustal growth in the central Slave craton at 3.55 Ga. Geochemical Perspectives Letters 10, 8-13.

SHAND, S.J. (1943) Eruptive rocks, their genesis, composition, and classification, with chapter on meteorites. J. Wiley \& Sons, Inc., New York.

TraIL, D., WATSON, E.B., TAILBY, N.D. (2011) The oxidation state of Hadean magmas and implications for early Earth's atmosphere. Nature 480, 79-82.

Trail, D., Tailby, N., Wang, Y., Harrison, T.M., BoehnKe, P. (2017) Aluminum in zircon as evidence for peraluminous and metaluminous melts from the Hadean to present. Geochemistry, Geophysics, Geosystems 18, 1580-1593.

Van Kranendonk, M.J., Collins, W.J., Hickman, A., Pawley, M.J. (2004) Critical tests of vertical vs. horizontal tectonic models for the Archaean East Pilbara Granite-Greenstone Terrane, Pilbara Craton, Western Australia. Precambrian Research 131, 173-211.

Voice, P.J., Kowalewski, M., ErIKSSON, K.A. (2011) Quantifying the Timing and Rate of Crustal Evolution: Global Compilation of Radiometrically Dated Detrital Zircon Grains. The Journal of Geology 119, 109-126.

WANG, Y., TRAIL, D. (2019) Aluminum partitioning between zircon and haplogranitic melts: The influence of temperature and melt composition. Chemical Geology 511, 71-80

WATSON, E.B., HarRISON, T.M. (2005) Zircon Thermometer Reveals Minimum Melting Conditions on Earliest Earth. Science 308, 841-844.

WeIss, B.P. et al. (2015) Pervasive remagnetization of detrital zircon host rocks in the Jack Hills, Western Australia and implications for records of the early geodynamo. Earth and Planetary Science Letters 430, 115-128. 